JURNAL SEKRETARIS \& ADMINISTRASI BISNIS

Jurnal homepage http /ljurnal asmtb ac id/inde $\times \mathrm{php} / \mathrm{jsab}$

\title{
ATTITUDE TOWARDS ENGLISH SLOGAN USED BY CULINARY PRODUCTS OF SMES AND HOW IT AFFECTS PURCHASE DECISIONS
}

Gartika Rahmasari $^{1}$ and Wawan Hendrawan ${ }^{2}$

${ }^{1,2}$ Universitas BSI; Akademi Sekretari dan Manajemen Taruna Bakti

${ }^{1}$ gartika.grm@bsi.ac.id; ${ }^{2}$ wawan.hendrawan@asmtb.ac.id

\section{ARTICLE INFO}

Article history:

Received $23^{\text {th }}$ January 2018

Received in revised form $09^{\text {th }}$ February 2018

Accepted $20^{\text {th }}$ February 2018

\section{Keywords:}

English slogan,

purchase decision,

SME
Kata Kunci:

slogan berbahasa Inggris, keputusan

pembelian,

$U M K M$

\section{ABSTRACT}

This study is a qualitative study examining the perception and comprehension of consumers towards 6 English slogans used by Small and Medium Enterprises/ SMEs' culinary product, particularly fruit-based crackers. Slogans examined include Aruna ("original taste and crispy"), Jecko ("so crunchy), Matoh ("good things come to those who share"), Miun Chips ("Indonesian sweet cassava chips"), Paradis Crunch ("premium Indonesian banana chips"), and Zanana ("try it; love it; miss it"). There are 26 respondents participated in this study. As a result, the easiest translated slogan considered by respondents is Aruna ("original taste and crispy") as much as $96,2 \%$, and the most difficult slogan to understand is Matoh ("good things come to those who share") as much as $34,6 \%$. In addition, the slogans regarded as the easiest translated are Aruna and Zanana, where $100 \%$ of respondents confessed that they were able to translate both slogans. However, when asked to translate all 6 slogans, it is the slogan of Jecko which could be translated correctly by most, as much as $86,4 \%$ and the most difficult slogan to translate is the slogan of Miun Chips. In addition, Jecko has the slogan whose meaning is well understood by most of respondents, as many as $88,5 \%$ respondents and the slogan whose meaning is the most difficult to understand is the slogan of Miun Chips (30,8\%). This study suggested that the use of English slogans by SMEs' culinary product, despite how easy or difficult they are to be understood, did not affect buying decision. It is the package $(46,2 \%)$ and the taste of product $(34,6 \%)$ that become the main reason for consumers to make buying decision, besides the price $(15,4 \%)$ and halal sertificate $(3,8 \%)$.

Penelitian ini merupakan penilitian kualitatif yang menelisik tentang persepsi dan pemahaman dari para pembeli terhadap 6 slogan berbahasa Inggris yang digunakan oleh produk kulinari dari Usaha Mikro Kecil dan Menengah, terutama keripik berbahan buahbuahan. Slogan-slogan yang diteliti mencakup Aruna ("original taste and crispy"), Jecko ("so crunchy), Matoh ("good things come to those who share"), Miun Chips ("Indonesian sweet cassava chips"), Paradis Crunch ("premium Indonesian banana chips"), and Zanana ("try it; love it; miss it"). Ada 26 responden yang terlibat dalam penelitian ini. Hasil penelitian menunjukkan bahwa slogan 
yang paling mudah dimengerti oleh para responden adalah Aruna sebanyak 96,2\%, dan slogan yang paling sukar untuk dimengerti adalah Matoh sebanyak 34,6\%. Selain itu, slogan-slogan yang dianggap sangat mudah untuk diterjemahkan adalah Aruna dan Zanana, di mana 100\% dari responden menyatakan bahwa mereka mampu untuk menerjemahkan kedua slogan tersebut. Akan tetapi, ketika para respoden ditanya untuk menerjemahkan semua slogan, hanya slogan dari Jecko yang dapat diterjemahkan dengan benar oleh responden, sebanyak 86,4\%, dan slogan yang paling sulit untuk diterjemahkan adalah Miun Chips. Jecko juga mempunyai slogan yang maknanya dipahami dengan baik oleh kebanyakan responden, yaitu sebanyak 88,5\%, dan slogan yang paling sulit dipahami adalah slogan Miun Chips sebanyak 30,8\%. Penelitian ini menyimpulkan bahwa penggunaan slogan bahasa Inggris oleh produk kuliner UMKM, terlepas dari mudah atau sulitnya slogan-slogan tersebut dimengerti, tidak mempengaruhi keputusan pembelian. Alasan utama para konsumen memutuskan untuk membeli suatu produk adalah kemasan $(46,2 \%)$ dan rasa $(34,6 \%)$, selain harga $(15,4 \%)$ dan sertifikat halal $(3,8 \%)$.

@ 2018 ASMTB PRESS

\section{Introduction}

Fruits are usually consumed in a fresh condition. However, currently the fruit can be consumed as processed products, one of which is processed into a product of chips. To become chips, fruits are fried with a vacuum frying method to ensure the nutrients contained in the fruit are still preserved. Fruits that can be processed into chips include bananas, yams, cassava, and jackfruit.

Recently, many small and medium enterprises' (henceforward: SME) produce processed chips. They are packed in various variants to attract the attention of consumers. They are also packed with attractive packaging, such as using sealed plastic containers for easy opening and closing. In addition, there are many SMEs that use slogan to strengthen their products, especially English slogans.

According to Allen (2000: 1318), slogan is "a phrase used to express and make public a particular view, position or aim" and "a brief catchy phrase used in advertising or promotion." The use of English slogans shows that English has an important position, especially in Indonesia. Although it is a foreign language, not the main introductory language, it can be assumed that English is widely used in promotional media because it is considered to have prestige and ability to attract consumers' attention in purchasing decisions. However, do consumers understand English slogans used by manufacturers, in this case SMEs? Referring to this, the researchers want to analyze and describe the consumer appreciation of English slogan of culinary products of SMEs in Indonesia.

English-language slogan studied taken from 6 processed chips products that produced by SMEs. Slogans taken include Aruna (banana chips, slogan: "original taste and crispy"), Jecko (jackfruit chips, slogan: "so crunchy), Matoh (cassava chips, slogan: "good things come to those who share"), Miun Chips (sweet potato chips, slogan: "Indonesian sweet cassava chips"), Paradis Crunch (banana chips, slogan: "premium Indonesian banana chips"), and Zanana (banana chips, slogan: "try it").

Based on the background described previously, here is the formulation of the problem of this research is: How is consumer appreciation and comprehension to English slogan on SME culinary products and its relation with purchase decision? 


\section{Literature Review \\ Definition of Slogan}

According to The New Penguin English Dictionary (2000: 1318), slogan is "a phrase used to express and make public a particular view, position or aim" and "a brief catchy phrase used in advertising or promotion". On the other hand, Alwi (2003: 1080) stated that the slogan is an interesting or striking and memorable short sentence or phrase to explain the purpose of an ideology, organization, and political party. According to Widyatama in Samosir (2016), "slogans can be used as a hallmark of the company or product, so the existence of the slogan can be one reminder of the company or product. The slogan can also be used to help the brand in raising the audience awareness of a product and can represent the identity of a product". The slogan used by a company selling a product will bind the description used in the advertising article. As stated by Goddart (1998: 106), "The slogan is a tagline that is used in the advertising copy". Furthermore, Granat (2003: 76) express the ad phrase and the importance of a company's product.

On the other hand, Granat (2003: 76) mentions that there are three functions of the slogan. The first function is that the slogan should embrace the story indicated by the advertisement and the reader. The second slogan's function is that the slogan as an identification and help people to consider the company's brand. The final function of the slogan is the slogan to help improving the company's image in the eyes of the target audience.

\section{Function And Position of English Language}

English is an international language. It means that there are many people who use English as a medium of communication in everyday life. Huda (2000: 68) mentions that there are five reasons why English is referred to as an international language, include its linguistic features, number of speakers, the extent of geographic spread of language use, the importance of English in fields such as economics and business, and the use of English language by countries that have dominated economic, political and cultural activities.

With respect to the number of speakers, according to Crystal in Rahmasari (2014), there are approximately 1.5 billion English speakers worldwide, comprising approximately 329 million speakers of L1 (inner circle-inner circles), 430 million speakers of L2 (outer circle-circle-outer countries), and about 750 million English speakers as foreign languages in countries in the expanding circle - the outer circle.

English is widely used by countries that dominate world economic activity, such as the United States. As Crystal points out in Lauder (2008) that English has an important position in economics and business because the position of the United States as the number one country that has power in global business, so that organizations or companies that want to enter the international market should use English language. This is why many companies or entrepreneurs use English, that is to reach a wider market/ international market, including Indonesia.

Rahmasari (2014) states that "the influence of strong English usage can also be seen in products or commercial places that use English because English is considered prestigious." This is regardless of whether the consumer understands the English used by the product or the place.

\section{Purchase Decisions}

According to Kotler and Amrstrong in Rahmasari (2014: 116-117), there are five stages through which consumers make purchasing decisions: 
1. Problem introduction

The consumer buying process begins with the introduction of a problem in which the buyer recognizes a problem or need.

2. Information search

Consumers who are interested may find additional information, and if the consumer feels quite interested and realizes there is a satisfactory product, he or she will likely buy it.

3. Alternative evaluation

Consumers make choices on a number of brands through several stages of evaluation. Consumers can use careful calculation and logical thinking, or act spontaneously without judging, or on the advice of a friend or even a seller.

4. Purchase decision

There are two things that influence the consumer's decision to buy a product, that is, the attitude of others to the consumer's choice and the unforeseen circumstances that can alter purchasing goals previously owned by the consumer.

5. Post purchase behavior

Consumer attitudes toward purchased products lie in the relationship between consumer expectations and perceived product performance.

\section{Research Method}

This research is a quantitative research with descriptive format. Descriptive study is a "study that aims to explain, summarize the various conditions, various situations ... that the object of the study was based on what happened" (Bungin, 2005: 44). The sample of the study was taken from the questionnaire distributed to the respondents randomly (random sampling).

The distributed questionnaire contains questions about the culinary slogan of culinary products. There are two parts asked in the questionnaire, which is about comprehension and preference. For the comprehension, the respondents' understanding of English slogans is derived from four sub-sections.

In the first part, respondents were asked whether they understood the meaning of the slogan of each culinary product. This section was calculated using the likert scale of 4 points (strongly disagree, disagree, agree, and strongly agree).

In the second part, respondents were asked if they could translate the meaning of the slogan of each culinary product. This section was calculated using the likert scale of 0-2 points (do not know, no, yes). In the third part, respondents were asked to translate the meaning of the slogan of each culinary product. This section was calculated using a likert scale of 2 points (not answering, answering but not exactly, answering appropriately).

In the last section, respondents were asked to write down the meaning of each slogan. This section was calculated using a likert scale of 2 points (not answering, answering but not exactly, answering appropriately). For the preference section, respondents were asked what factors to consider when making a purchase of a product. 


\section{Result and Discussion}

To test the understanding of English slogan, six culinary products using English slogan were selected. Table 1 shows the slogan of the six selected products.

Table 1

Slogans of Culinary Products of SMEs

\begin{tabular}{cll}
\hline No & \multicolumn{1}{c}{ Product } & \multicolumn{1}{c}{ Slogan } \\
\hline 1 & Aruna & "original taste and crispy" \\
\hline 2 & Jecko & "so crunchy" \\
\hline 3 & Matoh & $\begin{array}{l}\text { "good things come to those who } \\
\text { share" }\end{array}$ \\
\hline 4 & Miun Chips & "Indonesian sweet cassava chips" \\
\hline 5 & Paradis Crunch & "premium Indonesian banana chips" \\
\hline 6 & Zanana & "try it; love it; miss it" \\
\hline
\end{tabular}

\section{Descriptive Analysis of Respondent Data}

Respondents of this study came from various backgrounds of gender, age and educational level. Questionnaires were distributed to respondents randomly or randomly sampled. Here is a description of the respondent's data.

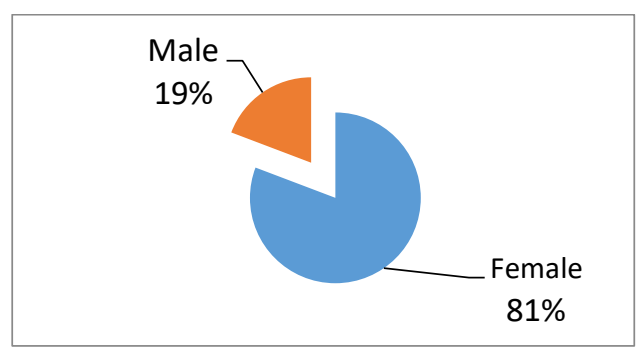

Figure 1

Gender of Respondents

Based on Figure 1 on the gender of the respondents, it is known that the number of female respondents is more than the number of male respondents, that is $80.2 \%$ or 21 people. On the other hand, the number of male respondents is $18 \%$ or 5 people.

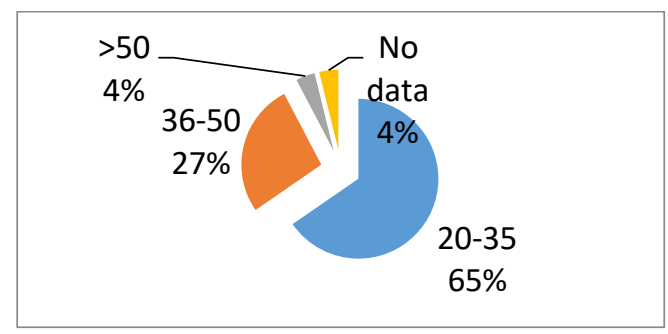

Figure 2

Age of Respondents

Based on Figure 2 on the age of respondents, it is known that respondents with age range 20-35 years were dominated as much as $65 \%$. Followed by respondents from the age range $36-50$ years, that is as much as $27 \%$. Respondents with ranges exceeding 50 years and respondents who did not include age data is of $4 \%$ or 1 person respectively. 


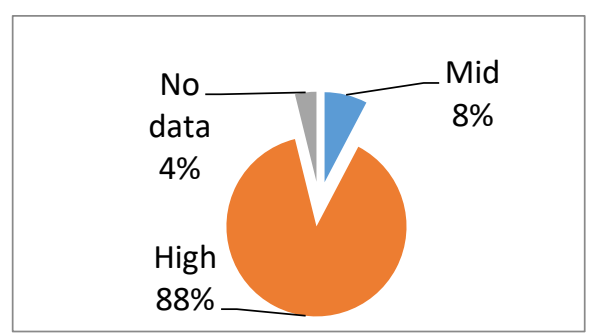

Figure 3

Education Level of Respondent

Based on Figure 3 on the level of education of respondents, the majority has a high education background, that is as many as $88 \%$ or 23 people, consisting of Diploma 1, Diploma 3, Bachelor Degree, Master Degree to Doctoral Degree. Respondents who are secondary school graduates amounted to 2 people, or by $8 \%$, i.e. high school graduates and vocational high school. While 1 respondent did not include educational background.

\section{Descriptive Analysis of Research Data}

Level of understanding of 6 English slogans was seen from the results of questionnaires distributed to 26 respondents. There are three parts that are asked, namely appreciation, comprehension and preference of respondents when making purchasing decisions. In the appreciation section, there are two proposed statements, namely that the respondent's understanding of the English language slogan (Likert scale 4 points) and that the respondent can translate the slogan (Likert scale 2 points). Then, for the comprehension, respondents were asked to translate each slogan (Likert scale 2 points) and write the meaning of slogan (Likert scale 2 points).

For the preference section, the subject is asked about the factors in making purchase decision. Respondents were given several options (packaging, taste, slogan, price, etc.)

Table 2 .

Respondents Understand the Meaning of English Slogans of SMEs' Culinary Products

\begin{tabular}{clrrrc}
\hline No. Statement & \multicolumn{3}{c}{ Respond } \\
\cline { 3 - 5 } & & $\begin{array}{c}\text { Strongly } \\
\text { Agree }\end{array}$ & Agree & Disagree & $\begin{array}{c}\text { Strongly } \\
\text { Disagree }\end{array}$ \\
\hline 1 & $\begin{array}{l}\text { I understand the slogan of Aruna "original } \\
\text { taste and crispy" }\end{array}$ & $19.2 \%$ & $76.9 \%$ & $3.8 \%$ & $0.0 \%$ \\
\hline 2 & $\begin{array}{l}\text { I understand the slogan of ecko "so } \\
\text { crunchy" }\end{array}$ & $19.2 \%$ & $65.4 \%$ & $15.4 \%$ & $0.0 \%$ \\
\hline 3 & $\begin{array}{l}\text { I understand the slogan of Matoh "good } \\
\text { things come to those who share" }\end{array}$ & $19.2 \%$ & $15.4 \%$ & $65.4 \%$ & $0.0 \%$ \\
\hline 4 & $\begin{array}{l}\text { I understand the slogan of Miun Chips } \\
\text { "Indonesian sweet cassava chips" }\end{array}$ & $30.8 \%$ & $57.7 \%$ & $11.5 \%$ & $0.0 \%$ \\
\hline 5 & $\begin{array}{l}\text { I understand the slogan of Paradis Crunch } \\
\text { "premium Indonesian banana chips" }\end{array}$ & $34.6 \%$ & $53.8 \%$ & $11.5 \%$ & $0.0 \%$ \\
\hline 6 & $\begin{array}{l}\text { I understand the slogan of Zanana "try it; } \\
\text { love it; miss it." }\end{array}$ & $23.1 \%$ & $53.8 \%$ & $19.2 \%$ & $3.8 \%$ \\
\hline
\end{tabular}

From table 2, it is known that there are five products whose slogan is understood by the majority of respondents, sorted from the most widely understood slogan of Aruna ("original taste and crispy") of 96.2\%, Miun Chips ("Indonesian sweet cassava chips") at 88.5\%, Paradis Crunch ("premium Indonesian banana chips") of $88.5 \%$, Jecko ("so crunchy") of $84.6 \%$, and Zanana ("try it, love it, miss it.") amounted to $76.9 \%$. On the other hand, respondents who claimed to understand the meaning of the slogan Matoh ("good things come to them who share") is only 34.6\%. It can be concluded that Matoh product slogan is not very understandable by the respondents. 
Table 3

Respondents are able to Translate English Slogans of SMEs' Culinary Products

\begin{tabular}{|c|l|c|c|c|}
\hline \multirow{2}{*}{ No. } & \multicolumn{1}{|c|}{ Statement } & \multicolumn{2}{|c|}{ Respond } \\
\cline { 3 - 5 } & Yes & No & $\begin{array}{c}\text { Don't } \\
\text { Know }\end{array}$ \\
\hline 1 & $\begin{array}{l}\text { I am able to translate the slogan of Aruna } \\
\text { "original taste and crispy" }\end{array}$ & $100.0 \%$ & $0 \%$ & $0 \%$ \\
\hline 2 & $\begin{array}{l}\text { I am able to translate the slogan of Jecko } \\
\text { "so crunchy" }\end{array}$ & $96.2 \%$ & $3.8 \%$ & $0 \%$ \\
\hline 3 & $\begin{array}{l}\text { I am able to translate the slogan of Matoh } \\
\text { "good things come to those who share" }\end{array}$ & $73.1 \%$ & $26.9 \%$ & $0 \%$ \\
\hline 4 & $\begin{array}{l}\text { I am able to translate the slogan of Miun } \\
\text { Chips "Indonesian sweet cassava chips" }\end{array}$ & $96.2 \%$ & $3.8 \%$ & $0 \%$ \\
\hline 5 & $\begin{array}{l}\text { I am able to translate the slogan of Paradis } \\
\text { Crunch "premium Indonesian banana } \\
\text { chips" }\end{array}$ & $88.5 \%$ & $7.7 \%$ & $3.8 \%$ \\
\hline 6 & $\begin{array}{l}\text { I am able to translate the slogan of Zanana } \\
\text { "try it; love it; miss it" }\end{array}$ & $100.0 \%$ & $0.0 \%$ & $0 \%$ \\
\hline
\end{tabular}

From table 3, it is known that there are 2 products where all respondents (100\%) claimed to be able to translate the meaning of the slogan of these products, namely Aruna and Zanana. From this data, it can be concluded that the slogan of these two products uses an easy-to-understand English vocabulary. The next slogans considered to use a simple English vocabulary is of Jecko's and Miun Chips', of which $96.2 \%$ of respondents claimed to be able to translate the slogan of those products. Followed by the slogans Paradis Crunch and Matoh (88.5\% and 73.1\%).

Table 4

Translation Result of Respondents toward English Slogans of SMEs Culinary Products

\begin{tabular}{clccc}
\hline \multirow{2}{*}{ No. Statement } & \multicolumn{3}{c}{ Respond } \\
\cline { 3 - 5 } & & $\begin{array}{c}\text { Less } \\
\text { Accurate } \\
\text { Translation }\end{array}$ & $\begin{array}{c}\text { Lccurate } \\
\text { Translation }\end{array}$ & $\begin{array}{c}\text { Not } \\
\text { Translating }\end{array}$ \\
\hline 1 & $\begin{array}{l}\text { Translation of slogan of Aruna "original } \\
\text { taste and crispy" }\end{array}$ & $73.1 \%$ & $26.9 \%$ & $0.0 \%$ \\
\hline 2 & $\begin{array}{l}\text { Translation of slogan of Jecko "so } \\
\text { crunchy" }\end{array}$ & $84.6 \%$ & $11.5 \%$ & $3.8 \%$ \\
\hline 3 & $\begin{array}{l}\text { Translation of slogan of Matoh "good } \\
\text { things come to those who share" }\end{array}$ & $57.7 \%$ & $19.2 \%$ & $23.1 \%$ \\
\hline 4 & $\begin{array}{l}\text { Translation of slogan of Miun Chips } \\
\text { "Indonesian sweet cassava chips" }\end{array}$ & $34.6 \%$ & $53.8 \%$ & $11.5 \%$ \\
\hline 5 & $\begin{array}{l}\text { Translation of slogan of Paradis Crunch } \\
\text { "premium Indonesian banana chips" }\end{array}$ & $80.8 \%$ & $11.5 \%$ & $7.7 \%$ \\
\hline 6 & $\begin{array}{l}\text { Translation of slogan of Zanana "try it; } \\
\text { love it; miss it" }\end{array}$ & $53.8 \%$ & $42.3 \%$ & $3.8 \%$ \\
\hline
\end{tabular}

From table 4, it is known that Jecko's slogan is the easiest translated slogan by respondents (84.6\%), followed by the slogan of Paradis Crunch as much as $80.8 \%$. The next slogan, quite easily translated, is the slogan of Aruna, which is as much as $73.1 \%$. On the other hand, there are three slogans that are rather difficult to translate, namely the slogan of Matoh because the respondents who can translate exactly as much as $57.7 \%$. Followed by the slogan Zanana, which amounted to $53.8 \%$. The slogan considered the most difficult to translate is the slogan of Miun Chips, because the number of respondents who can translate the slogan with accurate translation is only $34.6 \%$. This is because 
there were many respondents who did not know the meaning of sweet cassava as written in the slogan. Most respondents interpret it as "singkong manis" (cassava that is sweet) and not "sweet cassava" as referred to yam.

Table 5

The Result of Respondent's Interpretation towards English Slogans of SMEs' Culinary Products

Respond

\begin{tabular}{clccc}
\cline { 3 - 4 } No. Statement & & $\begin{array}{c}\text { Accurate } \\
\text { Interpretation }\end{array}$ & $\begin{array}{c}\text { Less Accurate } \\
\text { Interpretation }\end{array}$ & $\begin{array}{c}\text { Not } \\
\text { interpreting/ } \\
\text { Inaccurate } \\
\text { Interpretation }\end{array}$ \\
\hline 1 & $\begin{array}{l}\text { Interpretation of slogan of Aruna } \\
\text { "original taste and crispy" }\end{array}$ & $84.6 \%$ & 3.8 & $11.5 \%$ \\
\hline 2 & $\begin{array}{l}\text { Interpretation of slogan of Jecko "so } \\
\text { crunchy" }\end{array}$ & $88.5 \%$ & $0.0 \%$ & $11.5 \%$ \\
\hline 3 & $\begin{array}{l}\text { Interpretation of slogan of Matoh "good } \\
\text { things come to those who share" }\end{array}$ & $57.7 \%$ & $7.7 \%$ & $23.6 \%$ \\
\hline 4 & $\begin{array}{l}\text { Interpretation of slogan of Miun Chips } \\
\text { "Indonesian sweet cassava chips" }\end{array}$ & $30.8 \%$ & $46.2 \%$ & $26.9 \%$ \\
\hline 5 & $\begin{array}{l}\text { Interpretation of slogan of Paradis } \\
\text { Crunch "premium Indonesian banana } \\
\text { chips" }\end{array}$ & $61.5 \%$ & $11.5 \%$ & $19.2 \%$ \\
\hline 6 & $\begin{array}{l}\text { Interpretation of slogan of Zanana "try } \\
\text { it; love it; miss it" }\end{array}$ & $65.4 \%$ & $15.4 \%$ & \\
\hline
\end{tabular}

From table 5, it is known that the slogan of Jecko is the easiest translated slogan by respondents, because $88.5 \%$ of respondents can write the right interpretation, followed by the slogan Aruna $84.6 \%$. Four other product slogans are harder to interpret, such as the Zanana slogan where only $65.4 \%$ of respondents can write the exact interpretation of the slogan. Followed by Paradis Crunch of 61.5\%, and Matoh 57.5\%. The most elusive slogan is the meaning of Miun Chips, because only $30.8 \%$ of respondents can write the exact interpretation of the slogan. This is because there are many respondents who did not know the meaning of sweet cassava as written in the slogan. Most respondents interpret it as "singkong manis" (cassava that is sweet) and not "sweet cassava" as referred to yam.

In addition to asking about the consumer's understanding of the English slogan of SMEs'culinary products, researchers also asked about the reasons why respondents made purchasing decisions against a product. The results are presented in Table 6 .

Table 6

Reasons in Purchasing a Product

\begin{tabular}{clc}
\hline No & Reason of Purchase & Total \\
\hline 1 & Packaging & $46.2 \%$ \\
\hline 2 & Taste & $34.6 \%$ \\
\hline 3 & Price & $15.4 \%$ \\
\hline 4 & Halal & $3.8 \%$ \\
\hline
\end{tabular}

From Table 6, it can be seen that the main reason respondents buy a product is because of the packaging $(46.2 \%)$. In addition, the taste is also the other reason why respondents decide to buy a product, which is $34.6 \%$. What makes the price factor as the main reason to buy a product is only $15.4 \%$. In addition, there is only $3.8 \%$ of respondents who claimed halal as a major factor in buying 
a product. Thus, it can be concluded that respondents prioritize packaging and taste factors, compared to price factors and halal in making purchasing decisions.

\section{Conclusion}

Based on this study, it can be suggested that the perception of respondents' understanding of English slogans culinary products are not in accordance with the results of respondents' comprehension. This can be seen from the results of high perceptions, but inversely with the low results of comprehension (translation and meaning) for each slogan as described below:

1. The most understandable English slogan is Aruna, "original taste and crispy", as much as $96.2 \%$, while the most elusive slogan is Matoh, "good things come to them who share", around $34.6 \%$.

2. All slogans are considered easy to translate; however, Aruna and Zanana are thought the easiest translated slogan by respondents, as all respondents claim to be able to translate the slogan of these two products, and where $100 \%$ of respondents admit to be capable of translating these two slogans.

3. Despite the respondents confess Aruna is the easiest understood slogan, and Aruna's and Zanana's slogan are the easiest translated slogans, but the results of the respondents' questionnaires suggest otherwise. When asked to translate the slogan, Jecko's slogan is best translated correctly by respondents, that is as much as $86.4 \%$. On the other hand, the most difficult slogan translated is the slogan of Miun Chips ("Indonesian sweet cassava chips") because the majority of respondents cannot interpret sweet cassava as "yam", but translated as "singkong manis" (cassava that is sweet).

4. When asked to interpret the meaning of the slogan, again, Jecko's slogan is the most widely understood by respondent, about $88.5 \%$ of respondents. And the most difficult slogan interpreted is the slogan of Miun Chips, because only $30.8 \%$ of respondents can provide the right meaning.

5. Despite the above conclusions, it turns out that slogan is not included factors that determine a person's purchase decisions on a product. This is known from the survey of what factors are the main reasons used by respondents to buy a product. The findings show that the packaging around $46.2 \%$ and the taste of the product about $34.6 \%$ are the main reasons. Furthermore, the price (15.4\%) and halal (3.8\%) are also contributing. None of the respondents mentioned the slogan as a major factor in buying a product. Thus, it can be inferred that the use of English slogans by culinary products, regardless of easy or difficult to understand, has no impact on consumer purchase decisions.

\section{References}

Alwi, I. Z. (2003). Pasar Modal: Teori dan Aplikasi. Cetakan Pertama. Jakarta: Yayasan Pancur Siwah.

Bungin, B. (2005). Metodologi Penelitian Kuantitatif. Jakarta: Kencana Prenada Media.

Goddard, A. (1998). The language of Advertising. London.

Granat, J. (2003). Persuasive Advertising for Entrepreneurs and Small Business Owners. Jakarta: Kencana.

Huda, N. (2000). Kedudukan dan Fungsi Bahasa Asing (The Position and Function of Foreign Languages). In H. Alwi dan D. Sugono, Politik Bahasa: Risalah Seminar Politik Bahasa (Language Politics: Procedings of the Seminar on Language Politics), 59-78. Jakarta: Pusat Bahasa dan Departemen Pendidikan Nasional. 
Lauder, A. (2008). The Status and Function of English in Indonesia: A Review of Key Factors. Makara, Sosial Humaniora, 12 (1), 9-20.

Allen, Robert. (2000). The new Penguin English dictionary. Penguin.

Rahmasari, G. (2014). Korelasi Penggunaan Bahasa Inggris Dalam Penamaan Factory Outlet (FO) Di Bandung Terhadap Keputusan Pembelian. Jurnal Pariwisata, 1 (2): 114-121.

Samosir, D., Iis Kurnia Nurhayati, dan Syarif Maulana. (2016) "Hegemoni Penggunaan Bahasa Inggris dalam Slogan Perguruan Tinggi (Analisis Wacana Kritis Fairclough pada Slogan Dua Universitas Swasta di Kota Bandung).” Jurnal Sosioteknologi 15 (1): 124-135. 